\title{
ACTIVITIES OF THE ALL-UNION RESEARCH INSTITUTE OF GRAIN FARMING IN THE FRAMEWORK OF COMBATING SOIL EROSION IN VIRGIN REGIONS OF KAZAKHSTAN (1960-1970)
}

\author{
Arailym S. Mussagaliyeva \\ Eurasian National University, Nur-Sultan, Republic of Kazakhstan \\ Roza M. Mussabekova \\ Eurasian National University, Nur-Sultan, Republic of Kazakhstan
}

\begin{abstract}
Introduction. The history of the contribution of Soviet scientists to the development of virgin and fallow lands in Kazakhstan is one of the relevant and new topics in the study of the history of the USSR in modern society. Methods and materials. Studying the history of a large agricultural project of the Soviet Union is necessary to develop new concepts in modern historical science. In Soviet and modern historiography, historians have studied virgin soil as a political and economic reform of the state. In this vein, the contribution of Soviet scientists who solved the issues of environmental and economic efficiency of this agrarian reform was not sufficiently represented. The works do not present the fight against land erosion, organized by the All-Union Research Institute of Grain Farming located in Northern Kazakhstan. Analysis. For scientific work and research of virgin lands, the opening of the AllUnion Scientific Research Institute of Grain Farming in Northern Kazakhstan was necessary. Famous agricultural scientists worked at the institute; they conducted their research in the fields of Tselinny Krai. Academician A.I. Baraev, breeder, academician V. Kuzmin were among them. They were engaged not only in scientific work, but also in a short time saved the virgin lands of Kazakhstan. Their direct scientific work was related to the fight against land erosion and the protection of soils from wind erosion. At the Institute, scientists created new soil tilling tools and seeders, improved a new farming system, and created new highly productive varieties of crops. The Institute defended dissertations on topics related to the fight against land erosion, and conducted many scientific projects. Results. The work with new sources of local archives of Kazakhstan makes it possible to talk about the enormous contribution of Soviet scientists in the development of virgin and long-fallow lands of the arid North Kazakhstan and the development of agriculture in this region. Their experience and scientific results were invaluable in the agricultural sector of the republic.
\end{abstract}

Key words: All-Union Research Institute of Grain Farming, fight against soil erosion, A. Baraev, A. Zaytseva, E. Gossen, virgin lands.

Citation. Mussagaliyeva A.S., Mussabekova R.M. Activities of the All-Union Research Institute of Grain Farming in the Framework of Combating Soil Erosion in Virgin Regions of Kazakhstan (1960-1970). Vestnik Volgogradskogo gosudarstvennogo universiteta. Seriya 4. Istoriya. Regionovedenie. Mezhdunarodnye otnosheniya [Science Journal of Volgograd State University. History. Area Studies. International Relations], 2020, vol. 25, no. 3, pp. 31-44. (in Russian). DOI: https://doi.org/10.15688/jvolsu4.2020.3.3

УДК 94(574)“"1960/1970”:338.439.222

Дата поступления статьи: 16.07.2019

ББК $63.3(5 К а 3)-210.6$ Дата принятия статьи: 27.01.2020

\section{ДЕЯТЕЛЬНОСТЬ ВНИИ ЗЕРНОВОГО ХОЗЯЙСТВА В РАМКАХ БОРЬБЫ С ЭРОЗИЯМИ ПОЧВ В ЦЕЛИННЫХ РАЙОНАХ КАЗАХСТАНА (1960-1970-е ГГ.)}

\author{
Арайлым Сабитовна Мусагалиева
}

Евразийский национальный университет им. Л.Н. Гумилева, г. Нур-Султан, Республика Казахстан

\section{Роза Мадениетовна Мусабекова}

Евразийский национальный университет им. Л.Н. Гумилева, г. Нур-Султан, Республика Казахстан 


\section{СССР: ПРОБЛЕМЫ СОВЕТСКОЙ МОДЕРНИЗАЦИИ}

Аннотация. В данной статье раскрывается деятельность Всесоюзного научно-исследовательского института зернового хозяйства по борьбе с эрозией почв в освоении целинных и залежных земель в Северном Казахстане. Институт за короткое время стал центром ученых-аграрников всего Советского Союза. Научная деятельность ученых Института напрямую была связана с аграрной политикой страны, их исследования совпали с началом «целинного проекта» в острозасушливых районах Казахстана. В 1960-х гг. на целине появились первые экологические проблемы. Широкомасштабное освоение земли, вспашка плугами лишала поверхности пашни стерни, степь зимой обдувалась сильными ветрами, почва на огромных площадях оставалась без влаги, высыхала и распылялась. Проблемы усугубились развернувшейся на тот момент компанейщиной, когда каждый год вспаханные боронованием целинные земли увеличивались в площадях. Местные руководители в погоне за высокими результатами каждый раз стремились как можно больше вспахать свободных земель. В 1960-1970-е гг. ученые пытались решить проблему с эрозией почв. Неудивительно, что ВНИИ зернового хозяйства находился в самом центре Северного Казахстана. Его научная деятельность напрямую была связана с производством, то есть с практической деятельностью. Находясь в условиях идеологического надзора, ученые смогли добиться отличных результатов. Разработка новой системы земледелия, разведение новых высокоурожайных сортов сельскохозяйственных культур, создание сельхозяйственных машин и оборудования, целинного почвозащитного земледелия - все эти мероприятия смогли кардинально изменить сложившуюся ситуацию, решить проблему в максимально короткие сроки. В связи с этим в 1960-1970-е гг. коллектив ВНИИ зернового хозяйства усиленно занимался исследованиями в рамках борьбы с эрозиями почв в Северном Казахстане. Но их работа не была публичной, только после развала Советского Союза появились новые архивные документы, полно раскрывающие их научную деятельность и самоотверженный труд во благо казахстанской целины. Вклад авторов: А.С. Мусагалиева осуществляла общее руководство исследованием, изучала источники и историографию проблемы, редактировала окончательную версию; Р.М. Мусабекова выполнила интерпретацию источников, обзор литературы, написание текста статьи.

Ключевые слова: Всесоюзный научно-исследовательский институт зернового хозяйства, борьба с эрозией почв, А. Бараев, А. Зайцева, Э. Госсен, целина.

Цитирование. Мусагалиева А. С., Мусабекова Р. М. Деятельность ВНИИ зернового хозяйства в рамках борьбы с эрозиями почв в целинных районах Казахстана (1960-1970-е гг.) // Вестник Волгоградского государственного университета. Серия 4, История. Регионоведение. Международные отношения. - 2020. - Т. 25, № 3. - C. 31-44. - DOI: https://doi.org/10.15688/jvolsu4.2020.3.3

Введение. В 1954 г. в Казахстане началось освоение целинных и залежных земель северного региона республики. Надо признать, что в те годы аграрная реформа была крайне необходима народу. В 1950-е гг. советские люди жили чрезвычайно бедно. Как известно, до 1948 г. в стране действовала карточная система. В отдаленных областях Казахстана начался продовольственный кризис. В эти годы в республике аграрная сфера находилась в плачевном состоянии. В степном крае животноводство развивалось низкими темпами, а зернопроизводство практически было не развито. Воспоминания заместителя начальника Целинного краевого управления совхозов К.Д. Диярова о встрече с первым секретарем ЦК КПСС Н.С. Хрущевым: «Никита Сергеевич упрекнул казахстанцев в том, что при огромных возможностях животноводство в республике отстает, и по отдельным показателям оно находится ниже уровня 1928 года. Одновременно он выразил надежду, что с ос- воением целины и увеличением производства зерна можно будет резко поправить дела в животноводстве» [8, л. 1]. Таким образом, планировалось срочно решить проблему продовольствия в стране.

Конечно, сама идея освоения целинных и залежных земель была востребована, но неотвратимой оказалась надвигающаяся экологическая катастрофа. В первые годы целины стало ясно, что осваивать степь очень трудно. Приемы классического земледелия исчерпали себя уже в самом начале аграрной реформы. Причин было много. Когда началось освоение целины, земли были распаханы на больших площадях и это не было подкреплено научными изысканиями по данной проблеме. Без какого-либо учета распаханные земли быстро приходили в негодность, изменялся их качественный уровень, а орудия труда были и вовсе не изученными и не приспособленными для степных борозд. В результате началась ветровая эрозия. 
Ветровая эрозия была свойственна не только землям Казахстана. В 1930-е гг. в Канаде появились первые эрозии почвы. Исследование этой проблемы канадскими учеными позволило уже через несколько лет наладить работу против ветровой эрозии в этой стране.

16 октября 1956 г. по решению ЦК КПСС и Совмина СССР был организован Научно-исследовательский институт зернового хозяйства, который вошел в систему Казахского филиала Всесоюзной академии сельскохозяйственных наук имени В.И. Ленина (далее - ВАСХНИЛ). Институт расположился в острозасушливом районе - в 200 км от границы пустынь Центрального Казахстана, в Северном Казахстане, в самом центре казахстанской целины, в с. Шортанды Акмолинской области. В Институте работали видные ученые со всех уголков Советского Союза, академики, доктора наук, профессора аграрной науки.

Методы и материалы. Историография истории освоения целинных и залежных земель в Северном Казахстане разнобразна. В советской историографии тема целины исследовалась как хозяйственно-политическая кампания советской власти в аграрном секторе страны, поэтому во многих работах была отражена роль государства и партии в осуществлении данного проекта $[7 ; 12 ; 19 ; 22 ; 23]$. Проблема эрозии почв и почвозащитных мероприятий исследована только в трудах В. Куликова [20]. Он написал об этой проблеме как о уже решенной в первые годы казахстанской целины и деятельность Института представил общими работами. Таким образом, и в этой работе научные исследования и разработки советских ученых по изучению и внедрению эффективных мер борьбы с ветровой эрозией степных районов Северного Казахстана глубоко не изучены. Но эта проблема не была столь актуальной в советской историографии. В основном процесс оценивался как ошибка ушедшего с поста первого руководителя ЦК КПСС Н.С. Хрущева. Хотя борьба с эрозией и научные работы ВНИИ продолжались и в последующие годы, надо заметить, что идеологический запрет и недоступность архивных документов не позволили советским историкам раскрыть данную проблему.

После развала Советского Союза, безусловно, открылись архивные фонды и истори- ки получили прекрасную возможность работать с новыми материалами. Несмотря на это, в современной историографии большее освещение получили только экономические и социокультурные проблемы истории целинных и залежных земель в Казахстане. Это привело к тому, что исследовательское поле вопроса в целом ограничивается проблемами экономической эффективности, экологии и демографии.

Современные историки в своих работах представляют данную тему как экономическую политику советского государства. В их трудах много внимания уделено ошибкам целинной кампании, главное, на что они обращают свой взор, - это плюсы или минусы аграрных реформ [2; 32]. В трудах многих авторов особое место отводится экологическим проблемам $[1 ; 24]$. Безусловно, такие проблемы были, но перед советскими учеными ставились задачи, в которых они должны были решать не только вопросы экологической ситуации, но и проблемы экономической эффективности казахстанской целины.

Надо признать, что роли советских ученых, участвовавших в борьбе с эрозией почв, уделено недостаточно внимания. Именно Всесоюзный научно-исследовательский институт зернового хозяйства имени А. Бараева был такой организацией в степи. История Института и вклад его ученых в борьбу с эрозией почв исследуются учеными-аграрниками [21; 25], но остались без внимания историков.

Цель данного исследования - показать историю казахстанской целины на основе новых архивных документов, в том числе борьбу с эрозией почв, в которой ученые дали импульс развитию аграрного сектора и решению экологической проблемы Северного Казахстана. Цель определила необходимость решения следующих задач: раскрыть формирование и развитие Казахского НИИ зернового хозяйства, а также его переход на уровень всесоюзного значения, проанализировать вклад известных ученых в борьбу с эрозией почв.

Источниками данного исследования послужили документы, которые хранятся в фондах Всесоюзного научно-исследовательского института, партийные документы Института, а также личные фонды его сотрудников.

В работе применены общенаучные принципы объективности в изучении процессов, 


\section{СССР: ПРОБЛЕМЫ СОВЕТСКОЙ МОДЕРНИЗАЦИИ}

связанных с научной деятельностью ВНИИ. Архивные документы дают нам возможность воссоздать полную картину тех исторических событий.

Хронологические рамки работы охватывают период с начала 1960-х до конца 1970-х гг., в течение которого шла активная борьба ученых с эрозией почв целинных земель Северного Казахстана.

Анализ. Разговор о необходимости создания на казахстанской целине Научно-исследовательского института зернового хозяйства шел уже с 1955 года. Для Акмолинской области это было главным событием, в котором было задействовано все областное руководство. Председатель исполкома Акмолинского областного совета М.Е. Бутин и секретарь Акмолинского обкома партии Н.И. Журин написали письмо Министру сельского хозяйства B.В. Мацкевичу: «Распашка новых земель, осуществляемая здесь в больших размерах, расширение зернового хозяйства и развитие продуктивного животноводства поставили ряд важных и неотложных задач: по установлению рациональной системы земледелия обеспечивающей получение высоких урожаев сельскохозяйственных культур и дальнейшему ее совершенствованию, по созданию прочной кормовой базы и разработке мер по правильному содержанию продуктивного животноводства. Для быстрого решения этих задач на базе Шортандинской опытной станции и четвертого отделения совхоза КазЦИК Акмолинской области организуется Научно-исследовательский институт зернового хозяйства по обслуживанию северных, северо-восточных и западных областей Казахстана» [29, л. 5]. Из сводки директора Шортандинской опытной станции А. Голубева: «В связи с освоением новых земель и развитием продуктивного животноводства в Акмолинской и в других северных областях Казахстана возникла необходимость резкого расширения научно-исследовательских работ по различным вопросам сельского хозяйства и улучшения их качества» $[29$, л. 1].

ВНИИ зернового хозяйства был флагманом науки на казахстанской целине. Как сказал директор Института А. Бараев: «Перед молодым коллективом ученых этого института стояла предельна ясная задача: разрабо- тать эффективные меры по защите почв от ветровой эрозии, которая начала возникать на легких почвах Павлодарской и других областей с первого же года распашки на больших массивах. На карбонатных черноземных и каштановых почвах ветровая эрозия на значительных площадях стала приносить ущерб сельскому хозяйству уже в начале 1960 годов, после того как почва утратила свое естественное структурное строение» $[15$, л. 3]. Ученые Института сразу начали научно-исследовательскую работу в казахстанских степях.

В Институте работали известные ученые. Директором назначили члена-корреспондента ВАСХНИЛ А. Бараева. Он был основателем этого Института. В Институте работали селекционер, будущий академик ВАСХНИЛ и Герой Социалистического труда В. Кузьмин, заведующий отделом земледелия С. Сдобников, заведующая отделом агропочвоведения А. Зайцева. Институт распологал следующими отделами: отдел кормопроизводства (К. Постоялков), отдел кукурузы - (П. Хлебов), отдел экономики (В. Слободин), отдел агрохимии (О. Сдобникова), отдел овощеводства (В. Мохов), отдел садоводства (А. Гудзенко), отдел семеноводства (К. Камфорина). Таким образом, ученые Москвы, Ленинграда и других крупнейших городов страны прибыли в новый научный поселок.

В то время основное внимание народа было приковано к сельскому хозяйству. 26-28 февраля 1958 г. состоялось Первое Всесоюзное совещание, касающееся проблем ветровой эрозии, в постановлении которого Институту с привлечением опытных станций поручалось разработать программу исследований процессов ветровой эрозии и проведения практических мероприятий по ослаблению действия разрушения почв с дальнейшей разработкой мер защиты [9, с. 6]. Поэтому уже в августе 1958 г. в с. Шортанды на базе нового Института состоялась Первая выездная объединенная сессия ВАСХНИЛ и Казахской академии сельскохозяйственных наук, посвященная обсуждению системы земледелия в районах освоения целинных и залежных земель. В постановлении этого научного форума сказано, что «особое место в планах научных исследований должно быть отведено разработке широкого комплекса мероприятий по максимальному 
накоплению и рациональному использованию влаги, а также других мероприятий по поддерживанию и повышению эффективного плодородия почвы» $[14$, л. 50]. Таким образом, Институт стал центром науки в целинной кампании в СССР.

Итак, в результате исследований учеными Института было установлено, что надежная защита почв от ветровой эрозии возможна только при изменении системы обработки почвы, при отказе от плуга и переходе на ее обработку плоскорежущими орудиями, сохраняющими на поверхности полей стерни и другие растительные остатки [15, л. 4]. Из доклада директора НИИ зернового хозяйства А. Бараева: «В Казахстане освоение целинных и залежных земель осуществлялось в районах с особо острозасушливым климатом, с сильными ветрами зимой и после схода снега - весной. Практически освоение новых земель сводилось к их распашке плугами, тщательной разделке пласта дисковыми орудиями и зубовыми боронами, посеву зерновых культур дисковыми зерновыми сеялками и в дальнейшем к использованию этой же техники. Непригодность системы земледелия, заимствованной из европейских районов страны, и применения перечисленной техники в острозасушливых районах Казахстана были очевидны с первых дней освоения целины» [15, л. 1].

В 1956 г. в Институт из Карагандинской сельхозяйственной опытной станции перевелся известный ученый-почвовед А.А. Зайцева. В 1959 г. из Келлеровской опытной станции она привела молодого ученого, будущего академика Э.Ф. Госсена, который еще на Келлеровской опытной станции занимался оборудованием сельхозтехнической машины. Таким образом, в Институте началось создание новых методов борьбы с эрозией почвы.

14 апреля 1959 г. вышло Постановление Совета министров Казахской ССР «Об укрупнении экспериментального хозяйства Казахского научно-исследовательского института зернового хозяйства» с подписью первого секретаря Казахской ССР Д. Кунаева. После этого в целях расширения базы экспериментального хозяйства Казахского НИИ зернового хозяйства было принято предложение Акмолинского облисполкома, Министерства сельского хозяйства Казахской ССР и Казахской
Академии сельскохозяйственных наук о передаче Казахскому НИИ зернового хозяйства 4-го отделения зернового совхоза имени КазЦИКа в Шортандинском районе Акмолинской области со всеми землями (общая площадь - 7,2 тыс. га, из них пашни - 6,4 тыс. га), постройками, сооружениями, машинами, орудиями и другим имуществом, имеющимся на отделении, а также с планами сдачи государству зерна и других сельскохозяйственных продуктов. Акмолинскому облисполкому и Министерству сельского хозяйства Казахской ССР разрешили внести соответствующие изменения в землеотводные и учетные документы совхоза имени КазЦИКа [27, л. 1]. После этого началась огромная научная и практическая разработка целинной почвозащитной системы земледелия НИИ зернового хозяйства.

В 1961 г. Научно-исследовательский институт зернового хозяйства реорганизовали во ВНИИ зернового хозяйства. С этого дня Институт был учреждением союзного значения, в связи с чем улучшилась материально-техническая база Института, прибыло еще больше ученых из Центра. Повышая статус Института, государство дало возможность ученым больше заниматься производственными делами.

В этом же году произошли изменения и в административно-территориальном делении целинных областей Северного Казахстана. Указом Президиума Верховного Совета Казахской ССР от 26 декабря 1960 г. в составе Казахской ССР был образован Целинный край, в который вошли территории Акмолинской, Кустанайской, Кокчетавской, Павлодарской и Северо-Казахстанской областей. Этот крупный регион на севере Казахстана был создан для более полного использования огромных ресурсов и эффективного руководства.

Однако с каждым годом на казахстанской целине проблем не становилось меньше. Ни административно-территориальное деление, ни большие площади распаханных земель не спасли целинные земли.

Крупная эрозия почвы началась в 1962 году. В отчетах ученых написано, что «девятый вал» докатился до казахстанских степей. Ветры, достигая ураганной силы, поднимали в воздух тысячи тонн земли и несли 


\section{СССР: ПРОБЛЕМЫ СОВЕТСКОЙ МОДЕРНИЗАЦИИ}

почву за сотни и даже тысячи километров. Они уничтожили в Северном Казахстане сотни тысяч гектаров земли, вывели из строя на долгие годы огромные массивы, сделав их бесплодными [10, л. 10]. Между тем посевы зерновых культур в основном были сосредоточены в степных засушливых районах республики, для которых характерна повышенная деятельность ветров, вызывающих нередко пыльные бури. На легких почвах Павлодарской области в течение 5 лет (1955-1960 гг.) ветровой эрозией ежегодно повреждалось в среднем 187,5 тыс. га посевов. В 1961 г. эрозией в области было охвачено свыше 700 тыс. га пашни, весной 1962 г. - около 1,5 млн га, причем почва была повреждена на площади 275 тыс. га, а на 40 тыс. га повреждены посевы яровых культур. В отдельных хозяйствах ветровая эрозия приняла особенно большие размеры [5, с. 3]. Таким образом, ветровая эрозия стала наносить огромный ущерб сельскому хозяйству Северного Казахстана.

Под ветровой эрозией почвы понимается разрушение, интенсивное перемещение и отложение почвенных частиц при определенной скорости ветра. Ветер может уносить пыль со слабо задерновенных участков почвы. Ускоренная эрозия, которая проявляется в виде пыльных бурь, обусловлена энтропогенным фактором и нарушением сложившихся закономерностей в природе. Пыльные бури возникают в открытых степных пространствах, где поверхность почвы слабо защищена растительностью, и могут наносить огромный ущерб народному хозяйству, резко снижая плодородие почв [18, л. 62]. Нужны были срочные меры предовращения ветровой эрозии.

На ВНИИ зернового хозяйства была возложена задача спасти целинную землю. Ученые А. Бараев, С. Сдобников, П. Колмаков, А. Зайцева немало сделали для дальнейшей научной разработки вопросов целинного земледелия. В эти годы младшие научные сотрудники Б. Копеев, А. Бородкин защитили кандидатские диссертации. Все силы были направлены на борьбу с эрозией почвы, от этого зависел имидж казахстанской целины.

Аграрник К.И. Деревянко отмечал: «Безусловно, в глазах народа за период с 1959 по 1963 годы идея целины была скомпрометирована. Многие начали на нее смотреть с фатальной безнадежностью. Но не земля виновата и природа неплохая, не хуже канадской. Люди повинны, а главное, волюнтаризм, диктат, волевые необоснованные решения» [26, л. 17].

Ученые Института: агрономы, почвоведы, механизаторы - разрабатывали агротехнические требования на процесс обработки почвы, а затем ученые-механизаторы Института и ученые институтов инженерного профиля и конструкторы конструкторских бюро машиностроительных заводов создавали образцы экспериментальных почвообрабатывающих орудий и сеялок $[18$, л. 170$]$.

2 марта 1963 г. директор Института написал письмо заместителю председателя Совета министров СССР Д.С. Полянскому с просьбой оказать помощь в решении некоторых вопросов ВНИИ зернового хозяйства. В том числе в связи с тем, что Институт проводил научные разработки, направленные на принятие мер по борьбе с эрозией почв и мелиорации солонцов, появилась необходимость в организации лаборатории учета и оценки эродированных почв, противоэрозионной оценки орудий обработки почв и сеялок, плодородия дефинированных почв и мелиорации солонцов [13, л. 31-34].

Президиум ВАСХНИЛ созвал в июне 1963 г. при ВНИИ зернового хозяйства выездную сессию Академии, на которой обсуждались вопросы борьбы с эрозией почвы. В работе сессии участвовали около 400 ученых, руководящих представителей и специалистов Министерства сельского хозяйства СССР, партийных и советских органов, совхозов и колхозов республик, краев и областей страны [13, л. 1]. На этом совещании академик Т.Д. Лысенко поддержал теорию о раннем севе. Но директор ВНИИ зернового хозяйства А. Бараев категорически возражал против раннего сева.

В 1963 г. в книге ведущих ученых Института А.И. Бараева, А.А. Зайцевой, Э.Ф. Госсена «Борьба с ветровой эрозией почв» написано: «Авторы настоящей книги, изучив причины, способствующие ветровой эрозии, и механизм разрушения почвы, рассказывают о действенных агротехнических приемах, использование которых позволит ликвидировать эрозионно-опасные очаги» [5, с. 1]. Книга выш- 
ла своевременно, она была крайне необходима. В ней три главы: «Механизм разрушения почв при ветровой эрозии» (автор - А. Бараев), «Система мероприятий по защите эрозионно-опасных почв» (автор - А. Зайцева), «Машины и орудия для обработки эрозионно-опасных почв» (автор - Э. Госсен). В книге обобщаются исследования, проводимые ВНИИ зернового хозяйства степных областей Казахстана.

Одним из важных моментов было создание сельхозяйственных машин и оборудования для степных областей. Всесоюзный научно-исследовательский институт зернового хозяйства совместно со Всесоюзным научноисследовательским институтом механизации сельского хозяйства, Казахским институтом механизации и электрификации сельского хозяйства и конструкторами специальных конструкторских бюро заводов имени Октябрьской революции, Сибсельмашем, «Красной Звездой» и Алтайсельмашем разработали специальные почвообрабатывающие орудия и сеялки, приспособленные для работы на эрозионно-опасных почвах, и провели государственное испытание данных сельскохозяйственных машин на Целинной машиноиспытательной станции. По словам Э. Госсена, вместо плугов для основной обработки эрозионно-опасных почв необходимо применять рыхлители [6, л. 23]. С этого времени началась масштабная работа по созданию сельхозяйственных машин.

Вопрос этот положительно был решен в конце 1963 г., когда правительство обязало ряд заводов изготовлять противоэрозионную технику и было вынесено решение о строительстве в Целинограде крупного завода по производству противоэрозионной техники и о создании в Целинограде Государственного специального конструкторского бюро по противоэрозионной технике [18, л. 170]. Но эти работы затянулись на несколько лет.

Приход к власти Л.И. Брежнева, человека хорошо знающего казахстанскую целину, очень помогло ученым из ВНИИ зернового хозяйства. Он, по сравнению с Н.С. Хрущевым, предоставил ученым больше возможностей для разработки различных научных идей.

Первый секретарь ЦК КПСС Л.И. Брежнев сам несколько раз ставил перед учеными вопрос о необходимости разработки своей осо- бой целинной системы земледелия. Из ответа директора ВНИИ А.И. Бараева: «Мы, ученые, разумеется, полностью разделяли эту точку зрения, так как знали, что в условиях острозасушливого климата Казахстана применение этой техники неизбежно будет вызывать возникновение ветровой эрозии» $[15$, л. 2].

В 1965 г. ученые Института достигли высоких результатов. Проделана большая работа по всесторонней разработке и совершенствованию новой системы земледелия, созданию новых высокоурожайных сортов сельскохозяйственных культур, проверке в условиях своего хозяйства рекомендаций исследователей Института. Сотрудники Института в содружестве с целым рядом коллективов конструкторских бюро, заводов машиностроения разработали и создали новые машины и орудия, обеспечивающие возможность повсеместного применения в северных областях Казахстана безотвальной системы земледелия [30, л. 10].

В феврале 1965 г. сессия ВАСХНИЛ прошла в Целинограде. Разработанные Институтом основные положения целинного земледелия полностью одобрены сессией ВАСХНИЛ, а также нашли признание в областных партийных организациях, земельных органах, совхозахв и колхозах Северного Казахстана [30, л. 33].

Приемы целинного почвозащитного земледелия, разработанные на целинных землях, были одобрены в январе 1966 г. на выездной сессии ВАСХНИЛ в Целинограде и рекомендованы для широкого внедрения в производство в северных областях Казахстана и степных районах Сибири.

С этого дня ВНИИ зернового хозяйства стал центром по борьбе с эрозией почвы всего Советского Союза.

После организации промышленного производства противоэрозионной техники началось массовое внедрение этих приемов в производство. Совхозы и колхозы на собственном опыте убеждались в преимуществе почвозащитной системы земледелия. В результате освоения целинных и залежных земель, внедрения с 1966 г. основных приемов почвозащитного земледелия в северных областях Казахстана, а также Карагандинской, Актюбинской и Уральской областях существенно 


\section{СССР: ПРОБЛЕМЫ СОВЕТСКОЙ МОДЕРНИЗАЦИИ}

выросло производство зерна по сравнению предшествующей пятилеткой [15, л. 8].

20 марта 1967 г. вышло Постановление ЦК КПСС и Совета министров СССР «О неотложных мерах по защите почв от ветровой и водной эрозии». Почти ежегодно в Казахской ССР, в степных районах Западной и Восточной Сибири, а также на юге Украины, на Северном Кавказе и в ряде других зон страны пыльные бури выдували плодородный слой почвы, повреждали и уничтожали посевы на значительных площадях, а в отдельных районах засыпали орошаемые земли, ирригационные каналы и водные источники. К тому моменту в результате ветровой эрозии почв в Казахстане и в степных районах Сибири значительные площади пашни выбыли из оборота [28]. Надо было срочно решать эту проблему, ибо она могла привести к угрожающим последствиям.

Этому Постановлению предшествовали сессии ВАСХНИЛ по вопросам борьбы с водной и ветровой эрозией почв (Москва, 1963 г.) и Выездная сессия ВАСХНИЛ (Целиноград, 1966 г.), которые положили начало массовому внедрению в производство почвозащитной технологии возделывания зерновых культур. В Постановлении Выездной сессии ВАСХНИЛ 1966 г. говорится, что для борьбы с засухой и ветровой эрозией почв в северных районах Казахстана и в степных районах Западной Сибири первостепенное значение имеет внедрение новой технологии возделывания зерновых культур, основанной на применении обработок глубокорыхлителями с плоскорезами с оставлением стерни на поверхности почвы [18, л. 53]. Новые почвообрабатывающие орудия культиваторы-плоскорезы и стерневые сеялки - стали поступать в совхозы и колхозы в 1966 г. [18, л. 170]. Сессия утвердила жизненность новой целинной системы земледелия. Это была убедительная победа почвозащитной системы над пропашной в сухостепном земледелии Казахстана и Сибири.

После этого ученые ВНИИ зернового хозяйства стали более уверенно выполнять научные работы. В 1967-1968 гг. А. Бараев, Э. Госсен и А. Зайцева провели несколько Всесоюзных семинаров по обработке почвы и защите почв от ветровой эрозии. В 1968 г. Э. Госсен защитил кандидатскую диссерта- цию на тему «Обоснование противоэрозионных требований к почвообрабатывающим машинам и оценка почвозащитной технологии возделывания зерновых культур» в Бурятском сельскохозяйственном институте [10, л. 2]. Его работы были написаны на основе многолетних исследований на казахстанской целине. Он стал автором нескольких изобретений по защите почв от эрозии.

В Институте работал академик ВАСХНИЛ, Герой Социалистического Труда В.П. Кузьмин, который внес неоценимый вклад в селекционную работу Казахстана. Под его руководством были районированы сорта мягкой и твердой пшеницы. В 1966 г. в Институте учеными В.П. Кузьминым и В.И. Кандауровым был создан новый сорт яровой мягкой пшеницы «Целиноградка» [30, л. 41].

В 1968 г. А. Бараев с несколькими учеными побывал в Канаде, где они посетили опытные станции и семеноводческую ферму Министерства сельского хозяйства Канады, побывали в университетах нескольких провинций страны [15, л. 9-10]. ВНИИ зернового хозяйства во многом перенимал опыт канадских коллег для улучшения почвозащитного земледелия.

В этом году по рекомендациям лаборатории почвообрабатывающих машин была сконструирована борона БИГ-3 для закрытия влаги на стерневых фонах и передана на государственные испытания. По рекомендации лаборатории посевных машин была создана сеялка СЭС-2,1, а выявленные в процессе научно-исследовательских работ по сеялкам параметры были положены в основу при конструировании сеялок СКС-6 и СКС-12 [30, л. 82]. Академик А. Бараев при создании сельскохозяйственных машин работал вместе с молодым ученым Э. Госсеном.

Зимой и весной 1969 г. произошел резкий скачок ветровой эрозии. На многих полях распыление почв достигло крайне опасного предела, а в результате пыльных бурь на их поверхности накопился значительный слой перевеянного эрозионно-опасного мелкозема. Огромное количество мелкозема отложилось в полезащитных лесных полосах [4, с. 2].

В 1969 г. А. Бараев снова посетил Канаду. В газете «Целиноградская правда» была опубликована его статья «На фермах Канады», в которой он обращается к таким же 
актуальным проблемам: «Известно, что в 30-х годах этого столетия канадскому сельскому хозяйству ветровая эрозия наносила неисчислимые убытки. Ветровая эрозия была национальным бедствием страны и угрожала катастрофическими последствиями. Меры эти просты и доступны каждому фермеру. Везде на фермах в степных провинциях обработка почвы проводится безотвальными орудиями, чистые пары обрабатываются по полосам, чередующимися с полосами посева пшеницы и других зерновых культур. Посев производится в основном сеялками с трубчатыми рабочими органами и сеялками-лушильками. На почвах легкого механического состава, сильно подвергавшихся ветровой эрозии, пашня засеяна многолетними травами, которые используют на сено или пастбище для скота» [3]. Таким образом, А. Бараев привез из Канады технологию безотвальной обработки почвы с сохранением стерни.

После этого Комитет по науке и технике при Совете министров СССР поручил Институту координацию всех исследований в стране по защите почв от ветровой эрозии [18, л. 55]. Ученые активно включились в научноисследовательскую работу почвозащитного земледелия. В 1969 г. в Институте готовилось к изданию несколько книг, в том числе «Борьба с ветровой эрозией почвы» (А. Бараев, А. Зайцева), «Агробиологические особенности возделывания и методы селекции ярового ячменя» (И.Ф. Лошак), «Экономическая оценка севоборотов» (Н. Сафронов, П. Хлебов), «Противоэрозионная обработка чистого пара» (П. Хлебов), «Экономическая эффективность почвозащитной технологии» (В.М. Слободин, Л.В. Александров).

В 1970-1971 гг. были разработаны системы мероприятий по защите почв от ветровой эрозии для степных районов Северного Казахстана и Западной Сибири [14, л. 55]. В целом Институт в 1970 г. работал по 26 проблемам и 60 темам. Заложено свыше 300 опытов на площади 4000 га. Основным звеном разрабатываемой системы являлись почвозащитная обработка с применением комплекса почвообрабатывающих орудий и посевных машин, обеспечивающих сохранение стерни для защиты почв от ветровой эрозии. Внедрение почвозащитной обработки позволил пре- дохранить почву от ветровой эрозии. В 1970 г. продолжались работы по накоплению влаги и ее рациональному использованию. В этом же году проходили государственные испытания культиваторы-плоскорезы и глубокорыхлители [31, л. 16].

25 апреля 1972 г. коллективу ученых под руководством А. Бараева присуждена Ленинская премия. А. Бараев, А. Зайцева, Э. Госсен получили Государственную премию за участие в разработке почвозащитной системы земледелия, противоэрозионной техники и внедрения почвозащитной системы земледелия в производство [33, л. 11]. Премия была присуждена за результативные исследования ученым, которые для степных районов Северного Казахстана и Западной Сибири разработали системы мероприятий по защите почв от ветровой эрозии.

А.И. Бараев был руководителем Государственной научно-технической проблемы «Защита почв от эрозии» и задания «Разработать эффективные меры борьбы с ветровой эрозией почв». Под его руководством и при личном участии разработана и внедрена в производство почвозащитная система земледелия, включающая научные основы возделывания зерновых культур и комплекс агротехнических мероприятий по защите поля от ветровой эрозии [33, л. 11].

В 1972 г. на совещании в г. Кокчетаве Л.И. Брежнев сказал А. Бараеву: «Вы, Александр Иванович, многое сделали для целины, это общеизвестно, и мы Вас поддержали. Теперь мы просим Вас сделать то же самое для земледелия и в отношении сортов, в выведении местных высокоурожайных сортов зерновых. Но, учтите, у вас есть и много противников» $[11$, с. 78$]$. Дальнейшие исследования дали возможность коллективам ученых Института в Павлодарской опытной станции по защите почв от ветровой эрозии разработать целинную почвозащитную систему земледелия, обеспечивающую при комплексном внедрении ее приемов не только защиту почв от ветровой эрозии, но и получение более высоких и устойчивых урожаев зерновых культур и увеличение производства зерна в каждом хозяйстве [15, л. 6].

В 1974 г. в Целинограде проводилась выездная сессия ВАСХНИЛ. На сессии об- 


\section{СССР: ПРОБЛЕМЫ СОВЕТСКОЙ МОДЕРНИЗАЦИИ}

суждались пути интенсификация сельского хозяйства целинных районов, речь шла об использовании огромных резервов увеличения производства зерна на распаханных целинных землях, где создана хорошая основа для дальнейшей интенсификации сельскохозяйственного производства [18, л. 57].

В опытном хозяйстве Института внедрили почвозащитную систему земледелия. О том, что приемы почвозащитного земледелия завоевали должную популярность у земледельцев, свидетельствует их внедрение в производство. Практически за 10 лет их внедрение по стране на 1977 г. составило: обработка почвы без применения плуга 31,7 млн га, посев стерневыми сеялками 33,5 млн га. В Казахстане из 25 млн га зерновых культур в 1977 г. было засеяно стерневыми сеялками 20 млн га [16, л. 171].

Суть почвозащитной системы земледелия ВНИИ зернового хозяйства заключается: в применении для обработки почвы во всех острозасушливых областях республики вместо плугов плоскорежущих почвообрабатывающих орудий различного назначения для глубокой и полной обработки, сохраняющих на полях стерню и другие растительные остатки, вместо зубовых борон - игольчатых борон, вместо зерновых дисковых сеялок - стерневых сеялок СЭС-2,1; в оснащении совхозов и колхозов необходимым комплексом противоэрозионной техники; в максимальном накоплении снега на полях; во введении и освоении зернопаровых четырех- и пятипольных севоборотов с полем чистого пара; в проведении посева зерновых культур в оптимальные научно обоснованные сроки; в замене устаревших сортов зерновых культур [18, л. 7].

При комплексном применении приемов почвозащитного земледелия имело место существенное повышение урожаев зерновых культур.

В середине 1970-х гг. коренным образом поменялось положение при внедрении почвозащитной системы земледелия. Урожай зерновых культур до внедрения почвозащитной системы земледелия в 1965 г. составлял 5,9 ц/га; после ее внедрения в 1975 г. - 10,9 ц/га, в 1976 г. $-20,2$ ц/га, в 1977 г. - 12,0 ц/га, в 1978 г. - 21 ц/га. В среднем за 10 лет урожай яровой пшеницы по плоскорезной обработке по сравнению с осенней вспашкой плугами был выше на 4,8 ц/га [16, л. 175].

В 1978 г. коллектив Института выпустил книгу «Агротехнические рекомендации по проведению весеннего сева и обработке паров в совхозах и колхозах Целиноградской области» $[17$, л. 1-33], в которой ученые описали правильное проведение всех операций по предпосевной обработке почвы и посеву. В подготовке и написании книги принимали участие: академик А.И. Бараев, кандидаты сельскохозяйственных наук Э.Ф. Госсен, А.Ф. Готовец, И.Г. Зинченко, Н.М. Бакаев, М.К. Сулейменов, Н.В. Шрамко, А.М. Нестеренко, А.Ф. Кирдяйкин, И.В. Антонов, И.П. Охинько, кандидаты технических наук В.М. Акулов, А.С. Буряков, специалисты областного управления сельского хозяйства В.К. Хан, В.Е. Байдин. В книге отмечено: «В текущем 1978 году труженики сельского хозяйства Целиноградской области должны сдать и продать государству хлеба не менее 2 млн 30 тыс. тонн товарного зерна, полностью обеспечить хозяйства высококачественными семенами и выделить необходимое количества зерна на фураж. Для достижения такого уровня урожая хозяйствам области окажут помощь настоящие агротехнические рекомендации, разработанные коллективом ученых Всесоюзного научно-исследовательского института зернового хозяйства» $[17$, л. 3]. Этим подтверждается факт, что ученые Института управляли всеми сельхозяйственными работами целинной земли Казахстана, а также то, что они давали свои рекомендации, столь необходимые аграрникам. Вся многовекторная работа ученых Института, их самоотверженный труд говорит об их особом вкладе в экономику Северного Казахстана.

Ежегодное производство зерна в республике составило за 5 лет (1949-1953 гг.) до освоения новых земель 3,9 млн т; за 5 лет (1961-1965 гг.) до внедрения приемов почвозащитного земледелия - 14,5 млн т; за последующие годы после освоения основных приемов почвозащитного земледелия: в 19661970 гг. - 20,6 млн т; в 1971-1975 гг. 21,6 млн т; в 1976-1978 гг. - 25,1 млн т; в 1978 г. $-27,8$ млн т $[18$, л. 8].

В 1970-е гг. в Институте работали 14 заведующих отделами, 37 заведующих лабора- 
ториями, 52 старших научных сотрудника, 28 младших научных сотрудников, 31 старший агроном, инженер, 100 лаборантов-техников, 45 лаборантов [30, л. 37]. Из них 34 человека имели ученую степень.

Результаты. Таким образом, за короткое время Всесоюзный научно-исследовательский институт зернового хозяйства стал флагманом аграрной науки всего Советского Союза. Во многом успешное освоение целинных и залежных земель в Северном Казахстане и превращение республики в крупный аграрный сектор Советского Союза зависели от вклада советских ученых в освоение степи. Несмотря на трудности, им удалось создать почвозащитное земледелие в острозасушливых землях Казахстана.

Коллектив Института проводил исследования в области земледелия, агропочвоведения, механизации сельского хозяйства, селекции и семеноводства, экономики сельского хозяйства, кормопроизводства, удобрения, агролесомелиорации, защиты растений, овощеводства и садоводства. Также работали лаборатории технологии, физиологии растений и массовых анализов.

Важно заметить, что ученые ВНИИ зернового хозяйства, преданные своей миссии, до конца своих дней остались на земле, которую столь выхаживали. Они продолжили свои научные изыскания: защитили диссертации, улучшили материально-техническую базу, контролировали целинные земли по всему Северному Казахстану. Академик А.И. Бараев, А.А. Зайцева, В.П. Кузьмин и многие другие похоронены на земле Акмолинской области. Академик Э.Ф. Госсен проживает в г. Щучинске Акмолинской области на территории Института лесного хозяйства.

Труды ученых, посвященные почвозащитному земледелию, и сформировавшаяся их научная школа до сих пор востребованы, они служат развитию аграрного сектора современного Казахстана.

\section{СПИСОК ЛИТЕРАТУРЫ}

1. Абдирайымова, А. С. Хозяйственно-экономические, демографические и экологические последствия освоения целинных и залежных земель в Казахстане (1950-е-1990-егг. ХХ в.) : автореф. дис. ... канд. ист. наук / Абдирайымова Ардак Серикбаевна. - Алматы, 2007. -28 с.

2. Абылхожин, Ж. Б. Очерки социально-экономической истории Казахстана. XX век /Ж. Б. Абылхожин. - Алматы : Юат, 1997. - 360 c.

3. Бараев, А. И. На фермах Канады / А. И. Бараев // Целиноградская правда. - 1969. - 8 мая.

4. Бараев, А. Бороться с ветровой эрозией почвы / А. Бараев // Молот. - 1969. - 29 июля.

5. Бараев, А. И. Борьба с ветровой эрозией почв / А. И. Бараев, А. А. Зайцева, Э. Ф. Госсен. Алма-Ата : Казах. гос. изд-во с.-х. лит., 1963. -35 с.

6. Бараев, А. И. Борьба с ветровой эрозией почв : [рукоп. брошюра] / А. И. Бараев, А. А. Зайцева, Э. Ф. Госсен. - Алма-Ата : Казсельхозгиз, 1963 // Государственный архив Акмолинской области. Ф. 292. - Оп. 1. - Д. 24.

7. Винокурова, Р. Ф. Освоение целинных и залежных земель в Казахстане (1954-1958 гг.) : автореф. дис. ... канд. ист. наук / Винокурова Роза Федоровна. - М., $1962 .-20 \mathrm{c}$.

8. Воспоминания заместителя начальника Целинного краевого управления совхозов Диярова К.Д. о встрече с первым секретарем ЦК КПСС Хрущевым Н.С. // Государственный архив Акмолинской области. - Ф. 648. - Оп. 1. - Д. 28.

9. Госсен, Э. Ф. Избранные труды / Э. Ф. Госсен. - Щучинск : ИП Изотова В.В., 2011. - 512 c.

10. Госсен Эрвин Францевич. Биография // Государственный архив Акмолинской области. Ф. 1565. - Оп. 1. - Д. 21.

11. Гундарев, В. Р. Главный агроном целины / В. Р. Гундарев, Г. П. Рощин. - Алма-Ата : Кайнар, 1979. $-88 \mathrm{c}$.

12. Дауирбаева, Т. Деятельность местных Советов Казахстана по повышению материального благосостояния сельских тружеников целинных областей в 1954-1965 гг. (Кокчетавской, Кустанайской, Павлодарской, Северо-Казахстанской, Целиноградской) : автореф. дис. ... канд. ист. наук / Дауирбаева Тауекал. - Алма-Ата, 1983. - 27 с.

13. Докладная записка директора Института от 5 марта 1963 г. в ЦК КПСС «О мерах по борьбе с злостными сорняками в совхозах и колхозах Целинного края» // Государственный архив Акмолинской области. -Ф. 1031. - Оп. 1. - Д. 35.

14. Документы, характеризирующие научную, служебную деятельность А.И. Бараева // Государственный архив Акмолинской области. - Ф. 292.Оп. 1. - Д. 485.

15. Документы, характеризирующие научную, служебную и общественную деятельность А.И. Бараева // Государственный архив Акмолинской области. - Ф. 299. - Оп. 1. - Д. 498.

16. Документы, характеризирующие научную, служебную деятельность А.И. Бараева в 1978 г. 
// Государственный архив Акмолинской области. Ф. 292. - Оп. 1. - Д. 485.

17. Документы, характеризирующие научную, служебную и общественную деятельность А.И. Бараева // Государственный архив Акмолинской области. -Ф. 292.-Оп. 1. - Д. 66.

18. Документы, характеризирующие научную, служебную деятельность А.И. Бараева // Государственный архив Акмолинской области. - Ф. 292.Оп. 1.- Д. 495.

19. Досмаилова, С. Борьба партийных организаций Северного Казахстана за дальнейшее развитие сельского хозяйства (1956-1961 гг.) : (На материалах партийных организаций Кокчетавской, Кустанайской, Северо-Казахстанской, Павлодарской и Целиноградской областей) : автореф. дис. ... канд. ист. наук / Досмаилова С. - Павлодар, 1966. - 20 с.

20. Куликов, В. И. Целина-земля трудового подвига / В. И. Куликов. - М. : Политиздат, 1976. - 112 с.

21. Куришбаев, А. К. Целина для хлеба рождена : Уроки освоения целинных и залежных земель и реформирование аграрного сектора на современном этапе / А. К. Куришбаев // Нива. - 1999. - № 3. C. $10-16$.

22. Левченко, В. М. Роль советского государства в освоении целинных и залежных земель в Казахстане (1953-1958 гг.) : автореф. дис. ... канд. юрид. наук / Левченко В. М. - Алма-Ата, 1964. - 20 с.

23. Лысков, Ю. А. Партийно-организационная и партийно-политическая работа на селе в северных областях Казахстана в 1953-1958 годы : автореф. дис. ... канд. ист. наук / Лысков Ю. А. - АлмаАта, 1966. - 28 с.

24. Николаев, В. А. Экологические уроки полувекового опыта целинного земледелия / В. А. Николаев // Вестник Московского университета. Серия 5, География. - 2004. - № 6. - С. 3-9.

25. Пашков, С. В. Дефляции почв Северо-Казахстанской области / С. В. Пашков, А. В. Пигалев // Вестник ЗабГУ. -2016. - Т. 22, № 2. - С. 14-25.

26. Письмо Деревянко К.И., Дмитриевой М.П. и др. Бараеву А.И. // Государственный архив Акмолинской области. - Ф. 292. - Оп. 1. - Д. 135.

27. Постановление Совета Министров КазССР № 321 от 14 апреля 1959 г. «Об укреплении экспериментального хозяйства Казахского научно-исследовательского института зернового хозяйства» // Государственный архив Акмолинской области. Ф. 1031.- Оп. 1.-Д. 12.

28. Постановление ЦК КПСС и Совета министров СССР от 20 марта 1967 г. «О неотложных мерах по защите почв от ветровой и водной эрозии» // Правда. - 1967. - 2 апр.

29. Примерное Положение об Институте, утвержденное 25 октября // Государственный архив Акмолинской области. -Ф. 1031. - Оп. 1. - Д. 2.
30. Протоколы партийных собраний // Государственный архив Акмолинской области. - Ф. 685.Оп. 1. - Д. 28.

31. Протоколы партийных собраний // Государственный архив Акмолинской области.- Ф. 685. Оп. 1. - Д. 46.

32. Сактаганова, 3. Г. Аграрная политика тоталитарного государства в послевоенное десятилетие: формы и методы / 3. Г. Сактаганова // Вестник КазНУ им. Аль-Фараби. -2003. - № 2 (29). - С. 77-81.

33. Справки ВНИИЗХ о творческом вкладе Бараева А.И., Госсена Э.Ф., Зайцевой А.А. и др. в разработку почвозащитной системы земледелия, подготовленные для представления на Ленинскую премию // Государственный архив Акмолинской области. - Ф. 292. - Оп. 1. - Д. 406.

\section{REFERENCES}

1. Abdirajymova A.S. Khozyaystvennoekonomicheskie, demograficheskie i ekologicheskie posledstviya osvoeniya tselinnykh i zalezhnykh zemel v Kazakhstane (1950-e - 1990-e gg. XX v.): avtoref. dis. ... kand. ist. nauk [Economic, Demographic and Environmental Consequences of the Development of Virgin and Fallow Lands in Kazakhstan (1950s - 1990s of the $20^{\text {th }}$ Century). Cand. hist. sci. abs. diss.]. Almaty, $2007.28 \mathrm{p}$.

2. Abylkhozhin Zh.B. Ocherki sotsialnoekonomicheskoy istorii Kazakhstana. XX vek [Essays on the Socio-Economic History of Kazakhstan. $20^{\text {th }}$ Century.]. Almaty, Yuat Publ., 1997. 360 p.

3. Baraev A.I. Na fermakh Kanady [On the Canadian Farms]. Tselinogradskaya pravda, 1969, May 8.

4. Baraev A. Borotsya s vetrovoy eroziey pochvy [Fight Wind Erosion of the Soil]. Molot, 1969, July 29.

5. Baraev A.I., Zaytseva A.A., Gossen E.F. Borba $s$ vetrovoy eroziey poch $v$ [Fight Against Wind Erosion]. Alma-Ata, Kazakhskoe gosudarstvennoe izdatelstvo selskokhozyaystvennoy literatury, 1963. $35 \mathrm{p}$.

6. Baraev A.I., Zaytseva A.A., Gossen E.F. Borba s vetrovoy eroziey pochv: [rukop. broshyura] [Fight Against Wind Erosion. Handwritten Brochure]. AlmaAta, Kazselkhozgiz, 1963. Gosudarstvennyy arkhiv Akmolinskoy oblasti [State Archive of Akmola Region], F. 292, Op. 1, D. 24.

7. Vinokurova R.F. Osvoenie tselinnykh $i$ zalezhnykh zemel v Kazakhstane (1954-1958 gg.): avtoref. dis. ... kand. ist. nauk [Development of Virgin and Fallow Lands in Kazakhstan (1954-1958). Cand. hist. sci. abs. diss.] Moscow, 1962. 20 p.

8. Vospominaniya zamestitelya nachalnika Tselinnogo kraevogoupravleniya sovkhozov Diyarova K.D. o vstreche s pervym sekretarem TsK KPSS 
Khrushchevym N.S. [Memories of Deputy Head of the Virgin Regional Department of State Farms Diyarov K.D. About the Meeting with the First Secretary of the Central Committee of the CPSU Khrushchev N.S.]. Gosudarstvennyy arkhiv Akmolinskoy oblasti [State Archive of Akmola Region], F. 648, Op. 1, D. 28.

9. Gossen E.F. Izbrannye trudy [Selected Works]. Shchuchinsk, IP Izotova V.V., 2011. 512 p.

10. Gossen Ervin Frantsevich. Biografiya [Ervin F. Gossen. Biography]. Gosudarstvennyy arkhiv Akmolinskoy oblasti [State Archive of Akmola Region], F. 1565, Op. 1, D. 21.

11. Gundarev V.R., Roshchin G.P. Glavnyy agronom tseliny [Chief Agronomist of Virgin Lands]. Alma-Ata, Kaynar Publ., 1979. 88 p.

12. Dauirbaeva T. Deyatelnost mestnykh Sovetov Kazakhstana po povysheniyu materialnogo blagosostoyaniya selskikh truzhenikov tselinnykh oblastey v 1954-1965 gg. (Kokchetavskoy, Kustanayskoy, Pavlodarskoy, Severo-Kazakhstanskoy, Tselinogradskoy): avtoref. dis. ... kand. ist. nauk [Activity of Local Councils of Kazakhstan on Improvement of Material Welfare of Rural Workers of Virgin Areas in 1954-1965 (Kokchetav, Kustanay, Pavlodar, North Kazakhstan, Tselinograd). Cand. hist. sci. abs. diss.]. Alma-Ata, 1983. 27 p.

13. Dokladnaya zapiska direktora Instituta ot 5 marta 1963 g. v TsK KPSS «O merakh po borbe s zlostnymi sornyakami v sovkhozakh i kolkhozakh Tselinnogo kraya» [Report of the Director of the Institute of March 5, 1963 in the Central Committee of the CPSU "About Measures for the Fight Against Harmful Weeds in the State Farms and Collective Farms of the Virgin Krai"]. Gosudarstvennyy arkhiv Akmolinskoy oblasti [State Archive of Akmola Region], F. 1031, Op. 1, D. 35.

14. Dokumenty, kharakteriziruyushchie nauchnuyu, sluzhebnuyu deyatelnost A.I. Baraeva [Documents Characterizing the Scientific and Official Activity of A.I. Baraev]. Gosudarstvennyy arkhiv Akmolinskoy oblasti [State Archive of Akmola Region], F. 292, Op. 1, D. 485.

15. Dokumenty, kharakteriziruyushchie nauchnuyu, sluzhebnuyu i obshchestvennuyu deyatelnost A.I. Baraeva [Documents Characterizing the Scientific, Service and Social Activities of A.I. Baraev]. Gosudarstvennyy arkhiv Akmolinskoy oblasti [State Archive of Akmola Region], F. 299, Op. 1, D. 498.

16. Dokumenty, kharakteriziruyushchie nauchnuyu, sluzhebnuyu deyatelnost A.I. Baraeva v 1978 g. [Documents Characterizing the Scientific and Official Activity of A.I. Baraev in 1978]. Gosudarstvennyy arkhiv Akmolinskoy oblasti [State Archive of Akmola Region], F. 292, Op. 1, D. 485.

17. Dokumenty, kharakteriziruyushchie nauchnuyu, sluzhebnuyu i obshchestvennuyu deyatelnost A.I. Baraeva [Documents Characterizing the Scientific, Official and Social Activities of A.I. Baraev]. Gosudarstvennyy arkhiv Akmolinskoy oblasti [State Archive of Akmola Region], F. 292, Op. 1, D. 66.

18. Dokumenty, kharakteriziruyushchie nauchnuyu, sluzhebnuyu deyatelnost A.I. Baraeva [Documents Characterizing the Scientific, Official Activities of A.I. Baraev]. Gosudarstvennyy arkhiv Akmolinskoy oblasti [State Archive of Akmola Region], F. 292, Op. 1, D. 495.

19. Dosmailova S. Borba partiynykh organizatsiy Severnogo Kazakhstana za dalneyshee razvitie selskogo khozyaystva (1956-1961 gg.): (Na materialakh partiynykh organizatsiy Kokchetavskoy, Kustanayskoy, Severo-Kazakhstanskoy, Pavlodarskoy i Tselinogradskoy oblastey): avtoref. dis. ... kand. ist. nauk [Struggle of the Party Organizations of Northern Kazakhstan for Further Development of Agriculture (1956-1961) (On Materials of the Party Organizations of Kokchetav, Kustanay, North Kazakhstan, Pavlodar and Tselinograd Regions). Cand. hist. sci. abs. diss.]. Pavlodar, 1966. 20 p.

20. Kulikov V.I. Tselina - zemlya trudovogo podviga [Virgin Land - Land of Labor Feat]. Moscow, Politizdat, 1976. 112 p.

21. Kurishbaev A. Tselina dlya khleba rozhdena: Uroki osvoeniya tselinnykh i zalezhnykh zemel i reformirovanie agrarnogo sektora na sovremennom etape [Virgin Lands Are Born for Bread: Lessons of Developing Virgin and Fallow Lands and Reforming the Agricultural Sector at the Present Stage]. Niva, 1999, no. 3, pp.10-16.

22. Levchenko V.M. Rol sovetskogo gosudarstva $v$ osvoenii tselinnykh $i$ zalezhnykh zemel $v$ Kazakhstane (1953-1958 gg.): avtoref. dis. ... kand. yurid. nauk [The Role of the Soviet State in the Development of Virgin and Fallow Lands in Kazakhstan (1953-1958). Cand. jur. sci. abs. diss.]. Alma-Ata, 1964. 20 p.

23. Lyskov Yu.A. Partiyno-organizatsionnaya $i$ partiyno-politicheskaya rabota na sele $v$ severnykh oblastyakh Kazakhstana v 1953-1958 gody: avtoref. dis. ... kand. ist. nauk [Party-Organizational and PartyPolitical Work in Rural Areas in the Northern Regions of Kazakhstan in 1953-1958. Cand. hist. sci. abs. diss.]. Alma-Ata, 1966. 28 p.

24. Nikolaev V.A. Ekologicheskie uroki poluvekovogo opyta tselinnogo zemledeliya [Environmental Lessons from Half a Century of Virgin Farming]. Vestnik Moskovskogo universiteta. Seriya 5, Geografiya [Moscow University Bulletin. Series 5, Geography], 2004, no. 6, pp. 3-9.

25. Pashkov S.V., Pigalev A.V. Deflyatsii pochv Severo-Kazakhstanskoy oblasti [Deflation of Soils in North Kazakhstan Region]. Vestnik ZabGU 


\section{СССР: ПРОБЛЕМЫ СОВЕТСКОЙ МОДЕРНИЗАЦИИ}

[Transbaikal State University Journal], 2016, vol. 22, no. 2, pp.14-25.

26. Pismo Derevyanko K.I., Dmitrievoy M.P. i dr. Baraevu A.I. [Letter of Derevyanko K.I., Dmitrieva M.P. and Others to A.I. Baraev]. Gosudarstvennyy arkhiv Akmolinskoy oblasti [State Archive of Akmola Region], F. 292, Op. 1, D. 135.

27. Postanovlenie Soveta Ministrov KazSSR № 321 ot 14 aprelya 1959 g. «Ob ukreplenii eksperimentalnogo khozyaystva Kazakhskogo nauchno-issledovatelskogo instituta zernovogo khozyaystva» [Resolution of the Council of Ministers of the Kazakh SSR no. 321 of April 14, 1959 "On Strengthening the Experimental Economy of Kazakh Research Institute of Grain Farming"]. Gosudarstvennyy arkhiv Akmolinskoy oblasti [State Archive of Akmola Region], F. 1031, Op. 1, D. 12.

28. Postanovlenie TsK KPSS i Soveta ministrov SSSR ot 20 marta 1967 g. «O neotlozhnykh merakh po zashchite pochv ot vetrovoy i vodnoy erozii» [Resolution of the CPSU Central Committee and the USSR Council of Ministers of March 20, 1967 “About Urgent Measures to Protect Soils from Wind and Water Erosion"]. Pravda, 1967, April 2.

29. Primernoe Polozhenie ob Institute, utverzhdennoe 25 oktyabrya [Approximate Regulations on the Institute, Approved on October 25].
Gosudarstvennyy arkhiv Akmolinskoy oblasti [State Archive of Akmola Region], F. 1031, Op. 1, D. 2.

30. Protokoly partiynykh sobraniy [Minutes of Party Meetings]. Gosudarstvennyy arkhiv Akmolinskoy oblasti [State Archive of Akmola Region], F. 685, Op. 1, D. 28.

31. Protokoly partiynykh sobraniy [Minutes of Party Meetings]. Gosudarstvennyy arkhiv Akmolinskoy oblasti [State Archive of Akmola Region], F. 685, Op. 1, D. 46.

32. Saktaganova Z.G. Agrarnaya politika totalitarnogo gosudarstva $\mathrm{V}$ poslevoennoe desyatiletie: formy i metody [Agrarian Policy of the Totalitarian State in the Postwar Decade: Forms and Methods]. Vestnik KazNUim. Al-Farabi, 2003, no. 2 (29), pp. 77-81.

33. Spravki VNIIZKh o tvorcheskom vklade Baraeva A.I., Gossena E.F., Zaytsevoy A.A. i dr. v razrabotku pochv zashchitoy sistemy zemledeliya, podgotovlennye dlya predstavleniya na Leninskuyu premiyu [Documents of All-Union Scientific Research Institute of Grain Farming About the Creative Contribution of Baraev A.I., Gossen E.F., Zaytseva A.A., and Others in the Development of Soil Protecting System of Agriculture Prepared for Presentation at the Lenin Prize]. Gosudarstvennyy arkhiv Akmolinskoy oblasti [State Archive of Akmola Region], F. 292, Op. 1, D. 406.

\section{Information About the Authors}

Arailym S. Mussagaliyeva, Doctor of Sciences (History), Professor, Department of History of Kazakhstan, Eurasian National University, Satpaeva St., 2, 010000 Nur-Sultan, Republic of Kazakhstan, arai0410@mail.ru, https://orcid.org/0000-0002-1812-7152

Roza M. Mussabekova, PhD (Philology), Associate Professor, Department of Russian Philology, Eurasian National University, Satpaeva St., 2, 010000 Nur-Sultan, Republic of Kazakhstan, roza709@mail.ru, https://orcid.org/0000-0003-1471-8657

\section{Информация об авторах}

Арайлым Сабитовна Мусагалиева, доктор исторических наук, профессор кафедры истории Казахстана, Евразийский национальный университет им. Л.Н. Гумилева, ул. Сатпаева, 2, 010000 г. Нур-Султан, Республика Казахстан, arai0410@mail.ru, https://orcid.org/0000-0002-1812-7152

Роза Мадениетовна Мусабекова, $\mathrm{PhD}$ (филология), доцент кафедры русской филологии, Евразийский национальный университет им. Л.Н. Гумилева, ул. Сатпаева, 2, 010000 г. Нур-Султан, Республика Казахстан, roza709@mail.ru, https://orcid.org/0000-0003-1471-8657 